\title{
KOMPONEN PEMBELAJARAN PROGRAM LITERASI BUDAYA DI ECO BAMBU CIPAKU
}

\section{LEARNING COMPONENTS OF CULTURAL LITERACY PROGRAM IN ECO BAMBU CIPAKU}

\author{
Ari Putra, Jajat S. Ardiwinata, Viena Rusmiati Hasanah \\ Pendidikan Luar Sekolah, Universitas Pendidikan Indonesia \\ Jl. DR. Setiabudhi No.229, Isola, Sukasari, Kota Bandung \\ E-mail: arie_poetra67@yahoo.co.id, jajatsardiwinata@upi.edu, viena@upi.edu
}

Naskah diterima tanggal: 19-08-2018, disetujui tanggal: 09-10-2018

\begin{abstract}
This study aims to analyze the learning components developed by the ECO Bambu Cipaku institution, from learning devices, teaching materials and learning methods. Qualitative method used in this study whereas data were collected by interviews, document analysis, and observation, and was processed by using triangulation techniques. The results revealed that the ECO Bambu Cipaku institution makes the learning component in accordance with the learning needs of the community. The component is made in the form of a facilitator's guide for traditional game learning devices containing the value of character education and functioning as learning direction in accordance with learning signs. The use of expository learning methods in the form of lectures and question and answer is a model used by facilitators to transfer knowledge of cultural literacy based on traditional games. Thus, the innovation in cultural literacy learning developed at ECO Bambu Cipaku is in the form of a learning device serving as guidance to the learning process of traditional games even though cultural literacy programs through traditional game learning do not yet have special competency standards in the implementation process.
\end{abstract}

Keywords: learning components, cultural literacy, traditional games

Abstrak: Penelitian ini bertujuan untuk menganalisis komponen pembelajaran yang dikembangkan oleh lembaga ECO Bambu Cipaku, mulai dari perangkat pembelajaran, materi ajar dan metode pembelajaran. Metode yang digunakan dalam penelitian ini adalah metode kualitatif. Pengumpulan data menggunakan wawancara, analisis dokumen, dan observasi. Pengolahan data menggunakan teknik triangulasi. Hasil dari penelitian menunjukkan bahwa lembaga ECO Bambu Cipaku membuat komponen pembelajaran sesuai dengan kebutuhan belajar masyarakat. Komponen yang dibuat berupa panduan fasilitator untuk perangkat pembelajaran permainan tradisional yang bermuatan nilai pendidikan karakter dan memiliki fungsi mengarahkan pembelajaran sesuai dengan rambu-rambu pembelajaran. Penggunaan Metode belajar ekspositori berupa ceramah dan tanya jawab merupakan model yang digunakan oleh fasilitator dalam melakukan proses transfer ilmu pengetahuan pembelajaran literasi budaya berbasis permainan tradisional. Dengan demikian, inovasi pada pembelajaran literasi budaya yang dikembangkan di ECO Bambu Cipaku adalah berupa perangkat pembelajaran yang berfungsi sebagai pemandu proses pembelajaran permainan tradisional walaupun program literasi budaya melalui pembelajaran permainan tradisional belum memiliki standar kompetensi khusus dalam proses pengimplementasiannya.

Kata Kunci: komponen pembelajaran, literasi budaya, permainan tradisional 


\section{PENDAHULUAN}

Karakter dan beberapa perilaku menyimpang menjadi sorotan khusus dalam dunia pendidikan, masyarakat, dan keluarga. Permasalahan tersebut memasuki hal yang sangat kompleks, mulai dari aspek kehidupan manusia maupun aspek yang tidak mudah dijangkau, yaitu dunia maya. Masyarakat Indonesia, dikenal sebagai masyarakat yang berkarakter karena menjunjung tinggi nilai budaya ketimuran. Seiring dengan berjalannya waktu, nilai-nilai ketimuran yang menjadi identitas masyarakat Indonesia meliputi nilai kesopanan, kejujuran dan beberapa nilai lainnya seolah luntur bahkan mulai menghilang. Salah satu penyebabnya adalah arus globalisasi yang melanda bangsa ini dan dapat menggeser nilai-nilai karakter dan budaya masyarakat. Tiga hal yang harus dijalankan bersamaan dalam proses meningkatkan mutu pendidikan yaitu: aspek afektif, kognitif, dan psikomotorik (Tim Kreatif LKM UNJ, 2011).

Pada dasarnya karakter bersinggungan dengan hal-hal yang ada di dalam kehidupan manusia. Karakter merupakan jati diri, kepribadian, dan watak yang melekat pada diri seseorang (Ghufron, 2010). Pemerintah banyak mengembangkan program untuk menguatkan pendidikan karakter, mulai dari satuan pendidikan formal, pendidikan nonformal, bahkan pendidikan informal. Ada tiga hal yang mendasari individu agar berkarakter di antaranya, saling mengetahui satu sama lain, memiliki rasa peduli, dan menanamkan rasa amanah terhadap dirinya serta kelompok (Lickona, 1991).

Pendidikan karakter merupakan cara untuk mengarahkan seseorang dalam menjalani kehidupan sesuai dengan etika dan moral yang berlaku dalam suatu masyarakat (Istiningsih, 2016). Program yang berkaitan dengan pendidikan karakter dirangkum semenarik mungkin oleh pemerintah. Salah satunya terdapat pada program pendidikan nonformal yaitu literasi budaya. Pendidikan nonformal adalah model pendidikan yang bisa dikemas dalam bentuk beberapa program kegiatan belajar sesuai dengan kebutuhan masyarakat.

Menurut Judiani (2010) Tujuan Pendidikan Nasional sebagai rumusan kualitas yang harus dimiliki setiap warga negara Indonesia, dikembangkan oleh berbagai satuan pendidikan di berbagai jenjang dan jalur. Pendidikan nonformal merupakan jalur pendidikan yang diselenggarakan untuk semua usia. Kegiatan pembelajaran pada program pendidikan nonformal beragam dan dapat diimplementasikan dengan cara yang fleksibel sesuai dengan kebutuhan masyarakat. Pendidikan nonformal berdasarkan Peraturan Menteri Pendidikan dan Kebudayaan Nomor 81 Tahun 2013, menyelenggarakan program: pendidikan anak usia dini; pendidikan keaksaraan; pendidikan kesetaraan; pendidikan kecakapan hidup; pendidikan pemberdayaan perempuan; pendidikan kepemudaan; pendidikan seni dan budaya; dan/atau pendidikan nonformal lain yang diperlukan masyarakat. Program pendidikan nonformal yang berkaitan dengan penguatan pendidikan karakter, yaitu program literasi budaya. Program ini dianggap mumpuni untuk menjadi sebuah solusi dalam menghadapi tantangan abad 21.

Abad 21 juga memunculkan gagasan pendidikan untuk pembangunan berkelanjutan ( Affeldt, Weitz, Siol, Markic, \& Eilks, 2015). Pendidikan untuk pembangunan berkelanjutan (education suistanbility development) dapat digunakan sebagai alat dalam mempersiapkan generasi muda agar menjadi warga negara yang bertanggung jawab dan dapat berpartisipasi dalam lingkungan masyarakat. Program pendidikan pembangunan berkelanjutan ini di antaranya literasi budaya atau melek budaya. Program ini memiliki fungsi mengembangkan kemampuan peserta didik dalam rangka memahami dan menyikapi kebudayaan Indonesia sebagai identitas bangsa.

Literasi budaya yang dikembangkan sangat beragam, salah satunya adalah melek permainan 
rakyat. Permainan rakyat merupakan kegiatan yang bersifat tradisional dengan menggunakan alat ataupun lagu dan bisa digunakan oleh setiap kalangan. Menurut Kovaèeviæ (2013) permainan tradisional berhubungan dengan kehidupan desa, menjadi bagian dari masa kanak-kanak dan dalam kondisi hidup sederhana. Permainan terkait dengan beberapa aturan atau tujuan tertentu yang menghasilkan kegiatan dalam bentuk tindakan bertujuan (Nur, 2013). Permainan rakyat memiliki banyak muatan nilai karakter. Putra \& Hasanah (2018) mengemukakan bahwa terdapat hubungan antara nilai karakter dengan permainan tradisional. Pada permainan egrang memiliki nilai religius, peduli, dan kepercayaan diri. Permainan gobak sodor memiliki nilai peduli, percaya diri, dan kooperatif. Terdapat nilai kejujuran dan kepercayaan diri pada permainan cingciripit. Pada permainan bebedilan terdapat nilai kerjasama dan percaya diri. Permainan congklak memiliki nilai kejujuran. Melalui permainan tradisional anak-anak mendapatkan aturan sosial dan etika (Gelisli \& Yazici, 2015). Menurut Iwata, Yamabe, Polojärvi, \& Nakajima (2010) permainan tradisional menawarkan interaksi nyata untuk pemainnya. Sifat pembelajaran ini adalah pengisi waktu senggang, sebagai hiburan dan media edukasi.

Sarana pembiasaan dan penguatan nilainilai karakter juga bisa dilakukan melalui permainan tradisional. Permainan tradisional mengedukasi pemainnya untuk saling berbagi kepada sesama teman dan dapat berinteraksi langsung dengan pemain lawan. Melalui permainan tradisional setiap pemain bisa bersikap sportif pada setiap permainan. Sportif dalam menyikapi kemenangan dan menerima kekalahan. Setiap pemain harus menyelesaikan setiap permainan dari awal sampai akhir permainan. Hal ini mengajak pemain agar tidak boleh putus asa. Permainan tradisional dapat menciptakan kemampuan berpikir kreatif pemainnya. Melalui kegiatan ini anak-anak akan menjadi manusia dewasa yang kreatif (dalam hal positif tentunya) (Sudrajat \& Wijayanti, 2015).

Menurut Andriani (2012) permainan tradisional merupakan salah satu aset budaya yang mempunyai ciri khas kebudayaan suatu bangsa. Untuk itu, pendidikan karakter bisa dibentuk melalui permainan tradisonal. Ada kebermanfaatan dari program literasi budaya, salah satunya dapat menumbuhkan karakter dari peserta yang mengikuti pembelajaran.

Peraturan Menteri Pendidikan dan Kebudayaan Nomor 23 Tahun 2015 tentang Penumbuhan Budi Pekerti pada pasal 7 dijelaskan bahwa penumbuhan budi pakerti pada satuan pendidikan anak usia dini dan pendidikan masyarakat agar menyesuaikan dengan kondisi masing-masing (Kementerian Pendidikan dan Kebudayaan, 2015). Peraturan di atas memberikan otoritas kepada setiap jalur pendidikan untuk mengelola program dalam rangka penumbuhan budi pekerti. Menurut Mislia, Mahmud, \& Manda (2016) upaya untuk membangun karakter yang sesuai dengan kebudayaan nasional tidak hanya dilakukan di sekolah melalui serangkaian kegiatan belajar, tetapi juga melalui pembiasaan hidup.

Dalam kegiatan belajar mengajar, yang terjadi tidak hanya proses interaksi pendidik dan peserta didik. Pendidik tidak hanya memiliki peran sebagai orang yang memberikan transfer pengetahuan. Pendidik dalam hal ini sebagai fasilitator yang berperan sebagai pembimbing, pengembang, dan pengelola kegiatan pembelajaran. Dengan adanya pendidik diharapkan dapat memfasilitasi peserta didik untuk mencapai tujuan yang telah ditetapkan. Untuk mencapai tujuan pembelajaran diperlukan komponen pembelajaran. Komponen pembelajaran terdiri atas tujuan pembelajaran, materi ajar, dan metode ajar yang bisa digunakan sebagai penunjang pembelajaran (Riyana, 2008).

Literasi budaya yang dikembangkan oleh beberapa satuan pendidikan, tidak dituntut secara khusus untuk memiliki komponen 
pembelajaran secara sistematis. Hal ini dikarenakan program literasi budaya yang dikembangkan sesuai dengan kearifan lokal masing-masing daerah. Walaupun tidak memiliki kewajiban dalam membuat perangkat pembelajaran, tidak sedikit lembaga pengembang program ini membuat rencana pembelajaran. Tujuannya adalah agar dampak dari pembelajaran lebih terlihat. Fasilitator berinovasi untuk mengembangkan program ini agar memiliki komponen pembelajaran untuk dapat melihat keberhasilan pembelajaran. Dalam hal ini adalah penguatan nilai pendidikan karakter.

Komponen pembelajaran menjadi suatu hal yang krusial dalam mencapai tujuan pembelajaran termasuk dalam hal ini pendidikan nonformal. Jika dilihat dari pelaksanaannya, layanan pendidikan nonformal dijalankan dengan cara fleksibel. Tidak semua program pembelajaran di lembaga pendidikan nonformal diwajibkan untuk memiliki komponen pembelajaran khusus. Komponen pembelajaran tidak menjadi tolok ukur keberhasilan dalam proses belajar mengajar. Keberhasilan dalam penyelenggaraan program layanan pendidikan nonformal adalah pembentukan sikap dan keahlian.

Berdasarkan hasil observasi, Sanggar Seni Budaya dan Olahraga ECO Bambu Cipaku adalah layanan pendidikan nonformal yang bergerak di bidang pegembangan wisata edukasi. Satuan pendidikan nonformal tersebut mengadakan program literasi budaya berbasis permainan tradisional. Pengelola lembaga mengadopsi pembelajaran dengan menggunakan kurikulum berbasis kearifan lokal masyarakat Sunda. Program pembelajaran menggunakan kurikulum Bandung Masagi. Kurikulum ini mengusung nilainilai karakter di dalamnya dan berasaskan silih asih, silih asah, silih asuh dan silih wawangi. Hal ini membuat layanan pendidikan ECO Bambu Cipaku, semakin mantap dalam mengembangkan dan menyusun komponen pembelajaran untuk penyelenggaran program literasi budaya tersebut.

Lembaga pendidikan nonformal ini sudah memiliki komponen pembelajaran, mulai dari perangkat pembelajaran atau rencana pelaksanaan pembelajaran (RPP), materi ajar dan metode pengajaran yang digunakan oleh fasilitator untuk mengimplementasikan nilai-nilai karakter dan budaya sesuai tujuan yang diusung kurikulum Bandung Masagi. Komponen yang akan diteliti berupa perangkat pembelajaran, materi ajar, dan metode pengajaran. Tujuan dari penelitian ini berupa informasi mengenai pengembangan model program pembelajaran yang dilaksanakan pada layanan satuan pendidikan nonformal program wisata edukasi dan literasi budaya ECO Bambu Cipaku.

\section{METODE}

Penelitian ini menggunakan metode kualitatif yang mengajak untuk berfikir secara induktif dengan pendekatan studi kasus. Pendekatan studi kasus dilakukan karena permasalahan dalam penelitian ini hanya berlaku di lembaga ini saja. Data dideskripsikan dengan cara menguraikan, menggambarkan, dan menelaah komponen pembelajaran yang dikembangkan oleh ECO Bambu Cipaku. Teknik pengumpulan data dilakukan dengan menggunakan analisis dokumen, obeservasi-partisipasi, dan wawancara secara terbuka dan mendalam. Proses analisis dokumen dilakukan dengan cara mengumpulkan data berupa perangkat pembelajaran yang diciptakan oleh lembaga tempat penelitian berlangsung. Hal itu berfungsi sebagai alat untuk melakukan konfirmasi mengenai model pembelajaran, jenis permainan, dan penanaman nilai pendidikan karakter di satuan pendidikan nonformal. Observasi adalah proses yang dilakukan setelah mendapatkan informasi dari analisis dokumen untuk proses implementasi pembelajaran. Data penelitian dilengkapi dengan hasil wawancara untuk memvalidasi hasil penelitian dengan teknik yang 
digunakan. Wawancara dilakukan dengan tiga fasilitator yang terdapat di lembaga tersebut. Data informan menggunakan simbol nama $X, Y$, dan Z.

\section{HASIL DAN PEMBAHASAN \\ Perangkat Pembelajaran}

Berdasarkan hasil observasi, program literasi budaya berbasis permainan tradisional memiliki perangkat pembelajaran berupa RPP yang dibuat sesuai dengan jenis-jenis permainan yang diselenggarakan di ECO Bambu Cipaku. RPP tersebut digunakan sebagai panduan fasilitator dalam menyampaikan materi. RPP berfungsi sebagai alat untuk merencanakan kegiatan pembelajaran dalam jangka waktu singkat untuk mengatur jalannya pembelajaran. Pertanyaan Peneliti ( $P$ ) kepada fasilitator ( $F$ ) mengenai perangkat pembelajaran.

P: Apa landasan dasar fasilitator membuat RPP untuk kegiatan pembelajaran, bagaimana proses hingga terbentuknya RPP tersebut?

F: Ya, hal ini dilakukan atas dasar inisiatif para fasilitator agar kegiatan belajar mengajar menjadi terarah. RPP terbentuk sesuai dengan hasil diskusi yang dilakukan oleh fasilitator setiap melakukan pertemuan rutin. Tidak hanya itu, setiap menyelesaikan kegiatan-kegiatan pembelajaran, fasilitator langsung mencatat hasil pembelajaran untuk perbaikan dan masukan perangkat pembelajaran. Dari kegiatan tersebut maka terbentuklah RPP.

Fasilitator II dan III memberikan jawaban yang sama atas pertanyaan tersebut. Diskusi yang dilakukan oleh fasilitator dapat menjadi solusi pada setiap kesulitan yang dihadapi. Petunjuk teknis program literasi budaya, pada pedoman pelaksanaannya tidak ada ketentuan khusus untuk pembuatan RPP. Rancangan pembelajaran sebagai bentuk inisiatif fasilitator dibuat agar proses pembelajaran menjadi terarah dan materi sesuai dengan porsi dan kebutuhan belajar masyarakat. Fasilitator yang membuat rancangan pembelajaran adalah mereka yang sudah berkompeten pada bidang permainan tradisional dan pernah mengikuti pelatihan fasilitator permainan tradisional. Hal tersebut diperuntukkan agar rancangan pembelajaran tidak keluar dari konten yang diharapkan oleh lembaga. Rancangan pembelajaran tersebut dibuat sesuai dengan jenis permainan tradisional yang diselenggarakan di lembaga, seperti: cingciripit, boyboyan, surser, dan galah asin.

Dari studi dokumentasi, permainan tradisional yang menggunakan lagu atau kaulinan kakawihan lebih terkonsep karena peran fasilitator pada permainan ini lebih dominan. Tujuan utama diadakannya program literasi budaya ini adalah mengenalkan permainan tradisional kepada masyarakat agar tidak punah dan membangun karakter warga belajar, khususnya untuk anak-anak. Setiap permainan tradisional yang dibuatkan perangkat pembelajarannya mengandung nilai-nilai karakter bangsa. Tabel 1 adalah panduan teknis pelaksanaan program literasi budaya permainan tradisional Cingciripit.

Pada tabel 1 fasilitator membuat konsep RPP sesuai dengan kaidah prinsip pengembangan RPP. Menurut Mulyasa (2006) pengembangan RPP harus memperhatikan karaktistik dari peserta didik. RPP yang dikembangkan oleh fasilitator dikemas dengan nama "Panduan Teknis Pelaksanaan Program Literasi Budaya". Menurut responden, panduan teknis tersebut dipilih agar kegiatan pembelajaran lebih fleksibel. Pelaksanaan pembelajaran permainan tradisional dilakukan secara efektif dan efisien. Konsep panduan teknis RPP dibuat agar fasilitator bisa dengan mudah mengkondisikan diri di lapangan dan mampu memandu warga belajar. Agar tidak menyerupai dengan konsep pendidikan formal, maka panduan teknis untuk RPP berbasis permainan tradisional.

Di ECO Bambu Cipaku, nilai karakter pada RPP tidak ditampilkan secara tersurat. Nilai karakter pada permainan tradisional akan 
Tabel 1 Panduan Teknis Pelaksanaan Program Literasi Budaya Permainan Tradisional Cingciripit

\begin{tabular}{ll}
\hline Nama Program & Program Literasi Budaya \\
Nama Permainan & Permainan Cingciripit \\
Deskripsi Singkat & 1JP@45menit \\
& $\begin{array}{l}\text { Permainan ini dimaksudkan untuk mengembangkan } \\
\text { kecerdasan logika }\end{array}$ \\
\hline Tujuan Pembelajaran: & \\
\hline Kompetensi dasar & Setelah mengikuti program literasi budaya ini, \\
& peserta program diharapkan mampu mengenal dan \\
& memahami pesan-pesan positif yang terdapat pada \\
& permainan cingciripit \\
Indikator keberhasilan & 1) Peserta mampu mengetahui cara permainan \\
& Cingciripit \\
& 2) Peserta mampu mengetahui lagu pada permainan \\
& Cingciripit \\
3) Peserta mampu memahami pesan-pesan positif & yang terdapat pada permainan cingciripit \\
Materi Pokok dan Submateri Pokok: & Permainan Cingciripit \\
Submateri Pokok & 1) Cara permainan Cingciripit \\
& 2) Lagu pada permainan Cingciripit \\
& 3) Pesan-pesan positif yang terdapat pada \\
permainan Cingciripit
\end{tabular}

berbeda jika pemain yang memainkannya berbeda. Nilai karakter tersebut sesuai dengan kejadian saat di lapangan atau pada saat praktik. Di dalam pengembangan panduan teknis yang terdapat di ECO Bambu Cipaku terdapat tujuan instruksional. Tujuan tersebut berupa output yang ingin dicapai oleh lembaga dari hasil kegiatan pembelajaran. Hasil yang ingin dicapai yaitu setelah mengikuti program literasi budaya ini, peserta program diharapkan mampu mengenal dan memahami pesan-pesan positif yang terdapat pada permainan cingciripit.

Walaupun nilai karakter yang didapatkan tersirat, menurut Riyana (2008) tujuan instruksional harus terbagi atas tujuan umum dan khusus. Hal demikian dilakukan untuk mempermudah pendidik atau fasilitator dalam mengukur ketercapaian pembelajaran. Output yang diharapkan oleh lembaga adalah menguatnya nilai pendidikan karakter warga belajar setelah menerima materi mengenai literasi budaya. Nilai karakter yang tidak tertulis di dalam panduan teknis pelaksanaan program, dijelaskan secara langsung oleh fasilitator saat permainan dilakukan dan kegiatan penutup permainan. Sebagai contoh, hasil pengamatan saat memainkan cingciripit. Warga belajar diharapkan mengikuti aturan dengan jujur dan bertangung jawab atas apa yang telah dilakukan. Kesadaran akan kesalahan yang dibuat merupakan implementasi dari nilai karakter dalam diri warga belajar. Fasilitator menjelaskan kepada pembelajar dengan contoh yang berkaitan dengan kehidupan sehari-hari.

Alokasi waktu yang digunakan untuk memainkan cingciripit yaitu selama 45 menit. Dengan pembagian waktu 10 menit kegiatan perkenalan antara fasilitator dengan warga belajar. Fasilitator memberikan pertanyaan kepada warga belajar mengenai pemahaman mereka terhadap permainan tradisional, dalam hal ini permainan cingciripit. Kegiatan inti selama 
Tabel 2 Rencana Pelaksanaan Pembelajaran Cingciripit di ECO Bambu Cipaku

\begin{tabular}{|c|c|c|c|c|c|c|}
\hline \multirow[t]{2}{*}{ No. } & \multirow{2}{*}{$\begin{array}{l}\text { Tahapan } \\
\text { Kegiatan }\end{array}$} & \multicolumn{2}{|c|}{ Kegiatan } & \multirow{2}{*}{$\begin{array}{l}\text { Alokasi } \\
\text { Waktu }\end{array}$} & \multirow[t]{2}{*}{ Metode } & \multirow{2}{*}{$\begin{array}{c}\text { Media/Alat } \\
\text { Bantu }\end{array}$} \\
\hline & & Fasilitator & Peserta & & & \\
\hline 1 & $\begin{array}{l}\text { Pembukaan: } \\
\text { Perkenalan }\end{array}$ & $\begin{array}{l}\text { Fasilitator } \\
\text { memperkenalkan } \\
\text { identitas dirinya } \\
\text { Fasilitator bertanya } \\
\text { kepada peserta } \\
\text { mengenai } \\
\text { pemahaman } \\
\text { permainan } \\
\text { cingciripit } \\
\end{array}$ & $\begin{array}{l}\text { Peserta mendengarkan } \\
\text { pemaparan dari } \\
\text { fasilitator mengenai } \\
\text { identitas fasilitator } \\
\text { Peserta menjawab } \\
\text { pertanyaan fasilitator } \\
\text { mengenai pemahaman } \\
\text { permainan cingciripit }\end{array}$ & $\begin{array}{l}10 \\
\text { menit }\end{array}$ & $\begin{array}{l}\text { Ceramah } \\
\text { Simulasi }\end{array}$ & $\begin{array}{l}\text { Speaker, } \\
\text { Mic }\end{array}$ \\
\hline 2 & $\begin{array}{l}\text { Kegiatan } \\
\text { inti: } \\
\text { Pemaparan } \\
\text { materi } \\
\text { mengenai } \\
\text { permainan } \\
\text { cingciripit }\end{array}$ & $\begin{array}{l}\text { Fasiliator } \\
\text { mengintruksikan } \\
\text { kepada peserta } \\
\text { agar } \\
\text { tangannya kedua } \\
\text { diangkat dengan } \\
\text { posisi pada tangan } \\
\text { kanan menunjuk } \\
\text { kebawah dan } \\
\text { tangan kiri } \\
\text { membuka ke atas } \\
\text { Fasilitator } \\
\text { mengintruksikan } \\
\text { kepada peserta } \\
\text { bagaimana cara } \\
\text { permainan } \\
\text { cingciripit } \\
\text { Fasilitator secara } \\
\text { bersama-sama } \\
\text { dengan peserta } \\
\text { program } \\
\text { menyanyikan lagu } \\
\text { cingciripit } \\
\text { Fasilitator } \\
\text { menyampaikan } \\
\text { pesan-pesan positif } \\
\text { yang terdapat pada } \\
\text { permainan } \\
\text { cingciripit kepada } \\
\text { peserta }\end{array}$ & 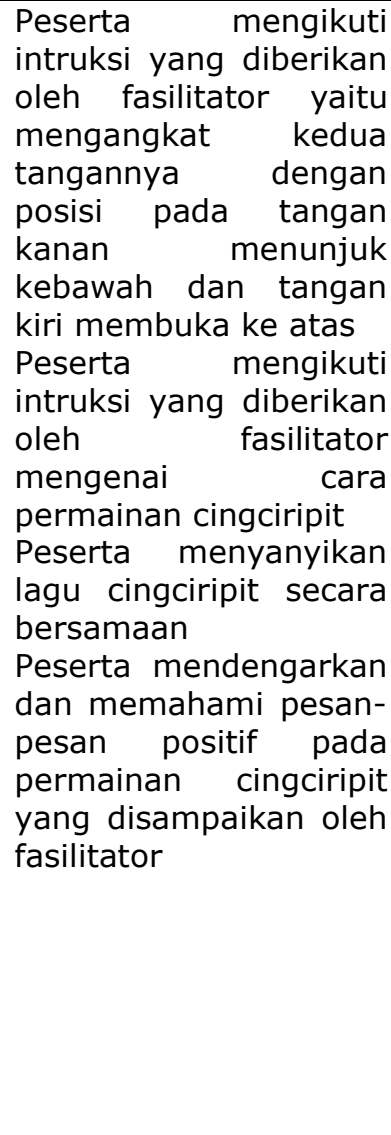 & $\begin{array}{l}30 \\
\text { menit }\end{array}$ & $\begin{array}{l}\text { Ceramah } \\
\text { Simulasi }\end{array}$ & $\begin{array}{l}\text { Speaker, } \\
\text { Mic }\end{array}$ \\
\hline 3 & $\begin{array}{l}\text { Penutup: } \\
\text { Kesimpulan } \\
\text { dan } \\
\text { terimakasih }\end{array}$ & $\begin{array}{l}\text { Menyimpulkan dari } \\
\text { makna } \\
\text { permainan } \\
\text { cingciripit } \\
\text { Mengucapkan } \\
\text { terimakasih }\end{array}$ & \begin{tabular}{lr}
\multicolumn{2}{l}{ Mendengarkan makna } \\
dari & permainan \\
cingciripit r & yang \\
disampaikan & oleh \\
fasilitator &
\end{tabular} & $\begin{array}{l}5 \\
\text { menit }\end{array}$ & Ceramah & $\begin{array}{l}\text { Speaker, } \\
\text { Mic }\end{array}$ \\
\hline
\end{tabular}

30 menit dilakukan fasilitator dengan memaparkan materi mengenai permainan tradisional. Pemaparan materi langsung dilakukan melalui kegiatan simulasi. Pada lima menit terakhir, fasilitator memberikan evaluasi dan menyimpulkan permainan yang telah dilakukan. Kegiatan ini merupakan kegiatan penutup dari permainan tradisional. Waktu tersebut dianggap cukup sesuai dengan kebutuhan belajar masyarakat. Di ECO Bambu Cipaku ada lebih dari lima permainan tradisional yang diberikan untuk kegiatan pembelajaran.

Setelah mengikuti kegiatan permainan tradisional warga belajar diharapkan untuk: 1) tidak lupa terhadap budaya dan kearifan lokal yang dimiliki oleh bangsa ini, 2) menguatnya 
pendidikan karakter di dalam diri sendiri sesuai dengan 18 nilai karakter yang terdapat di dalam pendidikan karakter, 3) mampu memecahkan dan menyikapi peramasalahan yang dihadapi, 4) menunjukkan kecintaan terhadap bangsa dan negara dengan keberagaman budayanya.

\section{Materi Ajar}

Materi ajar merupakan salah satu bagian penting dalam proses pembelajaran. Bahan ajar merupakan sumber belajar yang digunakan fasilitator agar peserta didik dapat semakin termotivasi dalam belajar untuk belajar. Mulyasa (2006) mengemukakan bahwa materi ajar merupakan salah satu bagian dari sumber ajar yang mengandung pesan pembelajaran, baik bersifat khusus maupun bersifat umum dan dapat dimanfaatkan untuk kepentingan pembelajaran. ECO Bambu terus melakukan perbaikan dan inovasi agar model pembelajaran literasi budaya bisa menjadi lebih baik mengembangkan materi ajar. Materi ajar yang digunakan oleh fasilitator terus dikembangkan berdasarkan pengalaman yang didapatkan di lapangan.

Berdasarkan hasil wawancara dengan tiga fasilitatorbahan ajar direvisi setelah proses pembelajaran selesai dilaksanakan. Fasilitator meyakini, untuk memperoleh materi ajar yang sesuai dengan tujuan pembelajaran di ECO Bambu Cipaku, perlu dilakukan revisi demi pembelajaran yang berkualitas. Isi materi ajar adalah dokumentasi beberapa lagu di dalam permainan tradisional dan maknanya. Fasilitator memilih kriteria pembelajaran yang sesuai untuk dimplementasikan dengan usia warga belajar yang berkunjung.

Ada beberapa kriteria yang dibuat oleh fasilitator dalam memilih materi ajar yang akan digunakan dalam pembelajaran, di antaranya: relevansi, kompleksitas, rasional, dan komprehensif (Riyana, 2008). Dari kriteria permainan yang dipilih dalam materi ajar, ditemukan bahwa warga tertarik dalam membaca materi dari fasilitator, apabila materi tersebut sesuai dengan kebutuhan mereka. Di dalam materi ajar, terdapat juga langkah-langkah permainan tradisional diselenggarakan di ECO Bambu. Hal ini dikuatkan oleh jawaban fasilitator dari hasil wawancara peneliti dengan fasilitator:

P: Apakah materi ajar yang digunakan fasilitator terdapat langkah cara memainkan permainan?

F: ya, di dalam materi ajar dijelaskan langkahlangkah permainan tradisional. Fungsinya adalah untuk memandu fasilitator menjelaskan cara permainan tradisional tersebut sama dengan fasilitator lainnya.

Pengembangan dan pemanfaatan bahan ajar dapat dilakukan dengan cara resources by design dan resources by utilization (Riyana, 2008). ECO Bambu Cipaku menerapkan pengembangan bahan ajar resources by utilization, yaitu memanfaatkan sumber-sumber yang ada di lingkungan sekitar untuk kepentingan belajar. Di dalam materi ajar yang disusun oleh fasilitator dijelaskan filosofi permainan tradisional. Fasilitator melakukan revisi beberapa lirik lagu dengan tujuan agar menjadi bermakna dan menarik untuk dimainkan pada Kaulinan Kakawihan, contohnya:

-SUR-SER-

Sur ser sur ser

Amis cau amis kumang

Jawadah tataleotan

Hileud sitataru ngambang

Euh euh tai manukan

Euh euh tai manukan

Bau tai hayam

(Sumber: ECO Bambu Cipaku)

Menurut informan $X$, sebelum melakukan permainan warga belajar diberikan filosofi dari permainan tersebut. Contohnya, Lirik lagu Sur ser di atas sarat akan makna. Sur ser merupakan singkatan dari surung seret yang berarti dorongan. Dalam Bahasa Sunda surung 
merupakan dorongan ke depan seret merupakan dorongan ke samping. Permainan ini digosokgosokan ke paha. Setiap manusia memiliki permasalahan. Setiap orang tua mengajarkan jika ada permasalahan harus bisa mencari solusinya.

Permainan Kaulinan Kakawihan mengajak pemainnya berfikir dewasa untuk mencari solusi dalam menghadapi permasalahan. Manfaat dari permainan juga dijelaskan di dalam materi ajar yang dikembangkan oleh ECO Bambu Cipaku. Misalnya, cingciripit memiliki manfaat bahwa hidup harus fokus terhadap tujuan yang kita buat. Apabila salah langkah maka kita akan terjebak. Pentingnya ketegasan dan ketangkasan menjalani hidup terdapat dalam materi ajar tersebut.

Saat ini, materi ajar yang digunakan oleh ECO Bambu Cipaku masih dalam penyusunan. Materi yang diberikan dikombinasi dengan buku sumbangan pemerintah yang terdapat di Taman Baca Masyarakat. Saat pembelajaran berlangsung, warga belajar dapat menggunakan buku bacaan yang ada di ruang baca ECO Bambu Cipaku untuk memahami maksud, tujuan bahkan langkah permainan tradisional.

\section{Metode Pembelajaran}

Dari hasil observasi, fasilitator menggunakan metode ceramah dan demonstrasi dalam pengajarannya. Demonstrasi lebih dominan digunakan oleh fasilitator. Menurut responden, pada permainan tradisional kegiatan pemberian pemahaman harus dicontohkan terlebih dahulu. $\mathrm{Hal}$ ini dimaksudkan agar warga belajar bukan dari daerah Jawa Barat atau yang belum mengetahui permainan tradisional menjadi paham akan permainan asli Jawa Barat.

Fasilitator mengungkapkan bahwa dengan menggunakan metode pembelajaran ekspositori, akan memiliki banyak kelebihan yang dapat menguntungkan warga belajar. Melalui metode ekspositori dapat mempermudah fasilitator mengontrol pembelajaran. Dengan demikian, fasilitator dapat mengetahui sejauh mana warga belajar dapat menguasai bahan pelajaran yang disampaikan. Untuk pembelajaran yang singkat seperti permainan tradisional, ekspositori mampu menjadi solusi yang efektif. Strategi pembelajaran yang digunakan dalam metode ekspositori yaitu warga belajar dapat mendengar melalui teknik ceramah dan dapat langsung mencoba permainan tersebut sehingga hasil antara teori dan praktik menjadi seimbang.

\section{SIMPULAN DAN SARAN Simpulan}

Komponen pembelajaran menjadi alat ukur dalam keberhasilan program pendidikan yang diselenggarakan. Fungsi komponen pembelajaran bagi lembaga ECO Bambu Cipaku menjadi panduan bagi fasilitator untuk mengarahkan warga belajar di setiap kegiatan belajar mengajar. Pembelajaran di ECO Bambu Cipaku pada program literasi budaya, menggunakan perangkat pembelajaran berupa panduan intruksional yang dirangkum dalam rencana pelaksanaan pembelajaran.

Kegiatan pembelajaran di ECO Bambu Cipaku menggunakan metode ekspostori dengan tujuan agar transfer pengetahuan berupa nilai karakter yang diberikan oleh fasilitator dapat diterima dengan baik oleh warga belajar. Fasilitator mampu menciptakan pembelajaran menjadi menarik dan menyenangkan dengan cara melakukan inovasi permainan supaya menjadi lebih seru. Fasilitator melakukan revisi dan menambah bait lagu pada beberapa kaulinan kakawihan yang ada pada permainan tradisional. Inisiatif dan inovasi ini terus dilakukan oleh pengelola dan fasilitator ECO Bambu Cipaku. Hal ini agar tercipta output pembelajaran yang berkarakter dan berkualitas.

\section{Saran}

Perlu adanya tahapan lanjutan berupa pengembangan bahan ajar dalam program literasi budaya yang diselenggarakan oleh setiap 
lembaga pendidikan nonformal. Tujuannya agar pembelajaran menjadi lebih bermakna. Literasi budaya utamanya adalah mengedukasi pembelajar agar tetap mampu mengenali dan memahami budaya Indonesia. Konsep melek budaya disertakan dengan kegiatan budaya baca, sehingga wawasan warga belajar semakin terbuka. Selain pengembangan bahan ajar, perlu dikembangkan buku pendamping pembelajaran agar implementasi literasi budaya tetap dapat dilakukan walaupun tidak adanya proses pembimbingan dari fasilitator. Lembaga pendidikan nonformal bergerak di bidang program literasi budaya harus memiliki langkah nyata dalam mengembangkan program. Model panduan teknis pembelajaran yang dikembangkan oleh ECO Bambu Cipaku dapat diadaptasi agar tercipta pembelajaran yang sesuai dengan tujuan instruksional. Hal ini dikarenakan belum adanya standar baku dalam petunjuk teknis dari program literasi budaya yang membahas perangkat pembelajaran program tersebut.

\section{PUSTAKA ACUAN}

Andriani, T. (2012). Permainan tradisional dalam membentuk karakter anak usia dini. Sosial Budaya, 9(1), 121-136.

Affeldt, F., Weitz, K., Siol, A., Markic, S., \& Eilks, I. (2015). A non-formal student laboratory as a place for innovation in education for sustainability for all students. Education Sciences, $5(3), 238-254$.

Gelisli, Y., \& Yazici, E. (2015). A study into traditional child games played in konya region in terms of development fields of children. Procedia-Social and Behavioral Sciences, 197, 1859-1865.

Ghufron, A. (2010). Integrasi nilai-nilai karakter bangsa pada kegiatan pembelajaran. Cakrawala Pendidikan, 29, 13-24.

Istiningsih. 2016. Character education of the most developed countries in ASEAN. Journal of Education and e-Learning Research, 3 (1), 32-37.

Kovaèeviæ, T., \& Opiæ, S. (2013). Traditional games and pupils' violent behaviour in elementary education. In Education Between Tradition and Modernity.

Iwata, T., Yamabe, T., Polojärvi, M., \& Nakajima, T. (2010). Traditional games meet ICT: a case study on go game augmentation. In Proceedings of the fourth international conference on Tangible, embedded, and embodied interaction, (237-240). ACM.

Lickona, T., (1991). Mendidik Untuk Membentuk Karakter "Bagaimana Sekolah Dapat Memberikan Pendidikan tentang Sikap Hormat dan Tanggung Jawab. Terjemahan oleh Juma Abdu Wamaungo. 2012. Jakarta: Bumi Aksara.

Judiani, S. (2010). Implementasi pendidikan karakter di sekolah dasar melalui penguatan pelaksanaan kurikulum. Jurnal Pendidikan dan Kebudayaan, 16(9), 280-289.

Mulyasa, E. (2006). Kurikulum tingkat satuan pendidikan sebuah panduan praktis. Bandung: PT Remaja Rosdakarya.

Kementerian Pendidikan dan Kebudayaan. (2015). Peraturan Menteri Pendidikan dan Kebudayaan Nomor 23 Tahun 2015 Tentang Penumbuhan Budi Pekerti.

Kementerian Pendidikan dan Kebudayaan. (2013). Peraturan Menteri Pendidikan dan Kebudayaan Nomor 81 Tahun 2013 tentang Pendirian Satuan Pendidikan Nonformal.

Nur, H. (2013). Membangun karakter anak melalui permainan anak tradisional. Jurnal Pendidikan 
Karakter, 3(1), 87-94

Mislia, M., Mahmud, A., \& Manda, D. (2016). The implementation of character education through scout activities. International Education Studies, 9(6), 130.

Putra, A. \& Hasanah, V. (2018). Traditional game to develop character values in nonformal educational institution. International E-Journal of Advances in Education, 4 (10), 86-92. DOI: $10.18768 /$ ijaedu.415411

Riyana, C. (2008). Komponen-Komponen Pembelajaran. Jakarta: Direktorat Jenderal Pendidikan Islam Kementerian Agama Republik Indonesia.

Sudrajat, W., \& Wijayanti, A. T. (2015). Muatan nilai-nilai karakter melalui permainan tradisional di PAUD Among Siwi, Panggung Harjo, Sewon, Bantul. Jurnal IImu Sosial UNY. Jipsindo, 2(1), 44-65.

Tim Kreatif LKM UNJ. (2011). Restorasi pendidikan indonesia: menuju masyarakat terdidik berbasis budaya. Ar-Ruz Media. Jakarta. 